\title{
Emotional Development and Psychological Adjustment
}

\author{
Ricardo Morgado Giraldo \\ Department of Research Methods and Diagnosis in Education (M.I.D.E.), University of Seville, Spain \\ Email: rmorgado@us.es
}

\begin{abstract}
In this work we take a tour of the main theories and approaches that studied affective development and the concepts of psychological adjustment and resilience. We start with the idea that there is an interconnection between these three factors. To verify this, we use data extracted from our study for T.D.E. (Emotional Development Test). With them we carried out the corresponding tests of contrast and established the relationship between the variables studied, together with the peculiarities of that relationship.

From all these investigations we conclude a close connection between affective and moral developments, together with a causal relationship of this pair with that of psychological adjustment and resilience, appreciating in the latter that it is not a constant throughout the life of individuals, but with a number of ups and downs, not necessarily pathological and the first as an equilibrium point, not as a fixed and immovable point.

Finally, we reflect on the application of these conclusions to the education of children and adolescents.
\end{abstract}

Keywords: emotional development, resilience, periods of crisis, emotional education.

\section{Introduction}

In the course of our research on affective development, we have found periods in the development of children and adolescents, but especially during adolescence, in which the so-called "negative emotions" are preponderant over positive ones. And although we start from the idea that affections are neither negative nor positive, but that these characters acquire the situations that trigger them, we plan that these periods (of a genetic-evolutionary nature, in the way in which they were posed Piaget) of the predominance of negative affects over others, are those that mark the periods of least emotional resilience, in the course of the individual's life and, therefore, can be considered times of crisis and greater vulnerability, which require more attention to the child or adolescent.

We also propose, in this work, that in those periods of crisis, emotional education should not consider educating emotions or controlling them, no matter how negative they may be; but to educate taking them into account and giving them expression, as the best way to solve the aforementioned crisis of personality growth.

One way to check if these adjustment periods are as we suspect, is the application and analysis of the results of the Emotional Development Test (T.D.E.).

Emotional development is presented as a set of situations in which talking about it in the abstract hardly seems to give us useful ideas, mainly because the idea of emotional development is based on concepts developed from preconceived ideas, and is not based on experimental practice or research, in any of its forms. We in this work, we will rely on the tests conducted with our TDE (Emotional Development Test "), to try to alleviate these deficiencies. We are going to do it, moreover, starting from the idea that affective life is not an abstract entity from which we barely know its intricacies but, to begin with, we can distinguish in it a whole conglomerate of affections, each one of them with its own dynamics and characteristics. Conglomerate of which you can make very different classifications, of which the most recognizable is the one that distinguishes between "positive affects" and "negative affects", distinction on which we have already discussed on several occasions (Morgado, 2013, 2015a, 2015b). And every time we raise this opposition we refer to our opinion that those who are truly "positive" or "negative"1 are the situations that provoke them, but that the triggered affects are adaptations to those situations

\footnotetext{
${ }^{1}$ Or, as Espinoza wanted, "derived from joy or sadness" (1980, pp. 170-178).
} 
or stimuli and, therefore, not they are rejectables in themselves. However, we propose that, although in each person there may be a predominance of favorable or unfavorable situations, for our emotional balance it seems appropriate that there be a balance between "negative" and "positive" emotions in each person. This balance will be obtained by the means that seem most convenient. From this balance, according to this point of view, a greater adjustment or psychological equilibrium must be derived and, as a consequence, a greater resilience or ability to adapt individuals to their different realities; and this with all its emotional "tools" at your fingertips, and not only with the overused "positive emotions" to which the so-called Positive Psychology has accustomed us (Fernández-Ríos and Vilariño, 2016). The emotional adjustment can thus be referenced to that balance derived from the fact that each affect has been deployed in an appropriate manner at each moment, the result of having given it the option to develop a full adaptive capacity.

This way, we have to say that we are not the only ones that relate psychological adjustment and affective world since as it gathers Fulquez Castro (2010):

\begin{abstract}
Martín-Jorge, Harillo and Mora (2008) under the word psychological adjustment investigate psychological well-being, which is related to levels of emotional intelligence. As psychological well-being, these authors study depression, anxiety, ruminative styles, life satisfaction and the perception of happiness. They found that perceived emotional intelligence (IEP) correlates negatively with psychopathological states, and that, on the contrary, there is a positive relationship between IEP levels and the perception of happiness and life satisfaction (p. 171).
\end{abstract}

Although we also bet for an estimate more in line with what our approaches are: we would dare to define the psychological adjustment not as the tendency towards states of happiness and satisfaction, but as the achievement of a balance in which the psyche does not see threatened its functionality; both in favorable and unfavorable situations, always within reasonably reasonable limits. That is to say, with a reasonably wide threshold of "comfort" and that, in some way, we could at some point measure, with which we would approach a true measure of "emotional health", far removed from the clinical model, as well as the biased positive psychology. We would leave, in this way, the so-called medical model, in which there are alterations or deviations from the "norm" and we would go towards a model in which what is valued are stages of development, each of which with its own "norm" without this norm signifying a rigid model, but a pattern of behavior in different life situations, that each individual must face in situations of different physical or mental development.

The patterns to which we refer, we try to find them through empirical research, for which the sampling made with our test T.D.E. These studies have revealed promising indications of how affective development is evolving, while providing us with clues about the relationship between moral and affective development, a relationship whose existence Espinoza himself already suspected, which considered emotions as "Passions" (that is, limitations or sufferings) and virtues as "powers of the soul" (op. cit.). Of course, vices are left absent in this scheme (thus assimilated indirectly to the passions), whereas the virtues, which are opposed to the vices in the usual ethical codes, do appear in this scheme.

This polarization of moral elements and affections is clearly manifested, although ignoring the vices, opposed to the virtues. From this polarization a connection between both psychic functions is suspected, although, as in the following quotation, the interest is rather in the "adequate" or not of each other, as we have been saying:

Seneca turns this tragedy (Medea) into a plea against the theory of Aristotle's passions. He believed that there could be a loving passion compatible with a morally good life. The virtuous person is expected to love the right kind of person, in the proper way, maintaining the right balance with his other acts and obligations. Seneca believes that this is an almost prudish naivety. (Marina, 2011, page 130).

And others establish the connection between affection, ethics and well-being / discomfort, as in the case of Tomás de Aquino, mentioned by Marina:

Thomas Aquinas [...]. Consider that sadness is the passion of the soul in front of a present evil. The different sorrows respond to different males. If the sadness for a real evil-for example, one's sins-is eloquent; but if it is for a false evil (that is, for an evil that is really a 
good) it is sin. Spiritual goods are real goods and that turns the acid into a sin, as opposed to charity. The ultimate root of acidia, says Thomas, is the confrontation of the desires of the flesh with those of the spirit. (Of bad, Q. 11, A. 2). (Marina, 2011; p 152) [laziness].

Moreover, Marina tells us that:

Aquinas follows the statement of Aristotle: no man can live permanently in sadness. He tends to flee from what saddens him, even if it is a good, as in the case of acidia. It risks, therefore, despair, but also indolence. In this flight is accompanied by hatred towards spiritual goods and hatred of spiritual goods and resentment against those who force him to that good." (Marina, 2011, page 152).

So we find in this search multiple samples of this connection between affections and ethics. These are examples in which some of them are generally prioritized, who are considered desirable and who fight against others, who are rejected in some way. Demonstrating with this, not already the connection between both spheres but the confused juxtaposition of both, that leads to consider desirable to some affections or others, quality of ethics and not of those. Here we see another example of Spinoza:

[...] Spinoza recommended that we combat a negative emotion with a more powerful but positive emotion produced by reason and intellectual effort. For his thought [...] The submission $^{2}$ of the passions must be achieved through the emotion induced by reason [...]. (Damasio, 2014: 23).

And is that Damasio is inclined to that version of rationalism, that makes distinctions between different emotions, at the same time that considers that as they are more controlled by reason so much better. In a kind of new cognition-emotion interactionism, which has its roots in a certain form of biological reductionism in which, sometimes, neuroscience falls.

\subsection{Resilience and Affectivity}

So, we have established a relationship between affectivity and ethics. We in the change, we have included in the adjustment, as a psychological balance maintained in the course of the insertion of each person in their different realities. We then consider another relationship with ethics: well-being can then proceed when the acts or realities of each one agree with what is desirable.

And, arrived at this point of understanding the adjustment when we arrived at the idea of resilience. We could start from the idea that emotion acts as a compensation with the cognitive and acts, at the same time, as a balancing factor that ensures greater stability and, therefore, greater adjustment. And this adjustment can be both cause and result of greater resilience. This resilience is understood in the sense given by Grotberg, E. H.: "Resilience is the human capacity to face, overcome and be strengthened or transformed by experiences of adversity" (Grotberg, E. H. 2003: 1). This idea of resilience can link, effectively with the role of maintaining equilibrium and adapting to the environment that has the affectivity, a way of processing the information that gives us reality, a more "ecological" and more adapted to the environment to process the information and plan the action that the cognitive one, which is centered in internal processes of reasoning and abstraction, by nature; and does not focus as much on the environment or environment as the way of processing and planning the affective action.

Thus, emotional adjustment, affective development and resilience appear related in a logical way; so that it may be useful for us to consider each other as markers. This is what we will do in this work.

In addition, to understand more clearly what happens when this emotional adjustment and the consequent disturbances that resilience can suffer, we can resort to theories such as Dabrowski's Theory of Positive Disintegration. This theory would explain the transformations of development as a sequence of five levels, understanding that in this way each individual will find tension, anxiety, despair and internal conflicts, which will not be understood as alterations, but mechanisms of adaptation, since considers that "The degree to which an individual is capable of achieving high levels of development is a function of their conditions for such development, psychic over-excitability and internal self-forces called dyna-

\footnotetext{
2 The italics are ours.
} 
mism." (Benito, 1992: 7). Which brings us back to the idea that greater resilience will act as a guarantee to overcome these consequent alterations with each dynamism.

And if we consider emotions as:

As the set of patterns and bodily responses, cognitive and behavioral at the same time that we adopt and apply people to what does not happen and also to what we create or project. They are more than simple answers to specific stimuli, they are cerebrally complex functions, which print a specific affective tone to the person and configure a mood or a way of being. They combine the innate, the lived and the learned. (Darder and Bach, 2006, p.66 cited (Gallardo, 2007: 4).

This idea will take us back to the connection between affectivity, adjustment and resilience. But this affective development should be related to moral development, prosocial behaviors (not skills), that guarantee balance after readjustments. And, in turn, the environment of an individual with high potential must facilitate situations in which they can develop values such as empathy, cooperation, high moral development, among others, so that emotional development is in the same parameters than cognitive development (Silverman, 1992, in Benito, 2004) and (George, 2000).

Based on all these reflections, we proceeded to carry out the present study, with the aim of finding an empirical relationship between affective development, moral development, emotional adjustment and resilience.

\section{Methodology}

The methodology of this research has been focused on finding moments of child and adolescent development during which moments of lesser resilience could occur, starting from the hypothesis that such moments should occur in the periods of change and transition. These periods would have to do with processes of assimilation and accommodation, as Piaget refers to the changes of cognitive stages, as well as with situations similar to those described - already on a more global level, and including the emotional one - Dabrowski (1977) in his theory of positive disintegration, referring to emotional overexcitability $^{3}$, which occurred probably in Phase II of multiple-level spontaneous disintegration (Santayana, 2004), which perhaps we can assimilate to puberty-first adolescence, from which one goes to the phases of organized multi-level disintegration (Phase III), possibly similar to the second adolescence and of Secondary Integration (Phase IV), probably established in young adults ${ }^{4}$.

Although this theory was developed based on the study of the evolution of gifted, however it has applicability to the general population, and this emotional overexcitability, alluded to Dabrowski, also includes: the intensity of feelings and inhibition, a very strong affective memory, the worry about death, anxieties, fears, guilt, depression and suicidal states. (Santayana, 2004: 9).

We started from a base similar to that of Dabrowski, and proceeded to study the possible evolution of the affections, to check patterns in that development. They were asked what emotions, feelings or affections they knew. Affects were considered in general, mainly because it was not specified in the test we used if they had to answer about emotions, feelings or other affections; mainly because we were interested in the types of affections ${ }^{5}$, not the kind of affections ${ }^{6}$. In principle, only the first answers expressed were taken into account, because the overall responses given by the subjects could correspond more to their rich vocabulary, than to their affective profile.

In addition, in the course of the investigation and with the delimitation of the types of affections, a frequent confusion appeared -in the speakers of the language- with ethic values, vices or virtues, which has made us reflect on this terminological confusion, which surely has to do with some kind of relationship between affective and moral development (Morgado, 2017).

\footnotetext{
${ }^{3}$ The others are: psychomotor, sensitive or sensual, imaginative and intellectual.

${ }^{4}$ However, these phases may be true that occur in these periods of life, mainly; but it could also be true that imbalances and disintegrations occur cyclically throughout the life of the human being, although with less or greater intensity on some occasions than in others.

${ }^{5}$ According to the 12 types we have considered.

${ }^{6}$ Emotions, feelings, moods...
} 
These types of affects to which we refer, are those that are exposed in the following illustration:

\begin{tabular}{|c|c|}
\hline "Negatives" & "Positives" \\
\hline Disappointment [expectations before the other -][1] & Admiration [expectations before the other +$][2]$ \\
\hline $\begin{array}{c}\text { Unhappiness / sadness / hopelessness / disillusion / } \\
\text { boredom / boredom / loneliness ["invalidating" } \\
\text { moods] [3] }\end{array}$ & $\begin{array}{l}\text { Happiness / happiness / hope / illusion / motivation } \\
\text { / tranquility / serenity [coadjuvant moods] [4] }\end{array}$ \\
\hline Anger / hatred / enmity [segregant affects] [5] & $\begin{array}{c}\text { Love / family / empathy / sympathy / friendship / } \\
\text { camaraderie [binding affects] [6] }\end{array}$ \\
\hline Guilt / shame / repentance [ego position -] [7] & Pride [ego position + ] [8] \\
\hline $\begin{array}{c}\text { Impotence / fear / stress / anxiety / jealousy / } \\
\text { insecurity [solidity of self-] [9] }\end{array}$ & Security / confidence [solidity of the self + ] [10] \\
\hline $\begin{array}{l}\text { Disgust / forced sexuality [viscerality-sensuality -] } \\
\text { [11] }\end{array}$ & Pleasure / sexuality [viscerality-sensuality + ] [12] \\
\hline
\end{tabular}

Figure 1. Negative and positive affects.

Once this conventional basis of positive and negative affects was established, a relationship was established between this dependent variable and the independent variable mainly considered in this work: time, established in age intervals.

This relationship is shown in the following tables, shown in the Results section, and for which the results obtained in the first response given in the Vocabulary test of our TDE have been taken into account. The first ones were used because it was estimated that these first answers could better express the prevalence of certain affects over others, and this is due to what seems to be a logical preference to express what concerns us the most. However, the set of responses of each subject was taken into account, although only as a volume of data.

The sample used is the one mentioned in previous works (Morgado 2013, 2015a, b and c and 2017). The same applies to the instrument used: the T.D.E.

For information purposes, we summarize here the characteristics of the T.D.E. test; said test was developed from a sample of 448 Primary and 476 Secondary School (E.S.O.) from various places in the western part of Andalusia, mainly Seville. The test consists of 2 parts, the first one in turn contains the following parts: 1) Object choice, 2) Cognitive elaboration of the object choice and 3) Emotional vocabulary. The second part consists of three other subdivisions: 1) Emotional impact, 2) Emotional style and Emotional balance. The subtest used was that of Emotional Vocabulary, which consists of asking young people or children to say how many affections, feelings or emotions they know, with no limit number, although there are a number of 70 lines on the sheet.

\section{Results}

Based on the criteria established in figure 1, we statistically treat the data obtained in the Primary and Secondary samples, these being expressed as follows:

\subsection{Results in Primary}

As we will see later, the data obtained and analyzed in Primary show results very similar to those of Secondary, but with differences in the significance of them, as we will explain:

\subsubsection{Results, in the first response, in grouped types}

In this section we collect the data referring to the first answers given by each subject (the first mentioned affection).

In Table 1, we simply describe the sample obtained, with the number of subjects of which we know their exact age, since some only indicated the age in years and we wanted to work with data that had the highest possible accuracy. 
Table 1. Case processing summary

\begin{tabular}{l|c|c|c|c|c|c}
\hline \multirow{2}{*}{} & \multicolumn{3}{|c|}{ Cases } & \multicolumn{3}{c}{ Total } \\
\cline { 2 - 7 } & \multicolumn{2}{|c|}{ Valid } & \multicolumn{3}{c|}{ Lost } & \multicolumn{2}{c}{ Percentage } \\
\cline { 2 - 7 } & $\mathrm{N}$ & Percentage & $\mathrm{N}$ & Percentage & $\mathrm{N}$ & $100,0 \%$ \\
\hline Types grouped in Response 1 * Intervals of 2 years & 394 & $87,9 \%$ & 54 & $12,1 \%$ & 448 & $1 \%$ \\
\hline
\end{tabular}

As shown in this table, according to the above criteria, of the 448 subjects in the sample, only the data of 394 of them were taken into account in the following tables, since 54 of them did not answer this item.

In Table 2 we present the crossed table of the grouped types of response (group-two in "positive" affects and "negative" affects, without taking into account the different classes of them), which reflects the expected and observed data, in the pre-set age ranges of 2 in 2 years (to filter the abrupt oscillations of the short age intervals). From this Table 2 differences are inferred between some periods and others.

Table 2. Cross table Types grouped in Answer $1 *$ Intervals of 2 years

\begin{tabular}{|c|c|c|c|c|c|c|c|}
\hline & & & \multicolumn{4}{|c|}{ Intervals of 2 years } & \multirow[b]{2}{*}{ Total } \\
\hline & & & $\begin{array}{l}6 \& 7 \\
\text { years }\end{array}$ & $\begin{array}{l}8 \& 9 \\
\text { years }\end{array}$ & $\begin{array}{c}10 \& 11 \\
\text { years }\end{array}$ & $\begin{array}{c}12 \& 13 \\
\text { years }\end{array}$ & \\
\hline \multirow{8}{*}{$\begin{array}{c}\text { Types grouped } \\
\text { in Answer } 1\end{array}$} & \multirow{2}{*}{ unanswered } & Count & 1 & 5 & 7 & 4 & 17 \\
\hline & & Expected count &, 4 & 5,2 & 9,5 & 1,9 & 17,0 \\
\hline & \multirow{2}{*}{$\begin{array}{c}\text { negative } \\
\text { affects }\end{array}$} & Count & 1 & 47 & 59 & 9 & 116 \\
\hline & & Expected count & 2,6 & 35,6 & 64,8 & 13,0 & 116,0 \\
\hline & \multirow{2}{*}{$\begin{array}{l}\text { positive } \\
\text { affects }\end{array}$} & Count & 7 & 65 & 139 & 27 & 238 \\
\hline & & Expected count & 5,4 & 73,1 & 132,9 & 26,6 & 238,0 \\
\hline & \multirow{2}{*}{ others } & Count & 0 & 4 & 15 & 4 & 23 \\
\hline & & Expected count &, 5 & 7,1 & 12,8 & 2,6 & 23,0 \\
\hline \multirow{2}{*}{\multicolumn{2}{|c|}{ Total }} & Count & 9 & 121 & 220 & 44 & 394 \\
\hline & & Expected count & 9,0 & 121,0 & 220,0 & 44,0 & 394,0 \\
\hline
\end{tabular}

As can be seen, positive affects predominate in three of the four periods, leaving only the period of 8 and 9 years as the predominance of negative ones; being, in addition in this period where the differences between the expected frequencies and the observed ones are bigger percentages speaking.

Table 3. Chi-square test

\begin{tabular}{cccc}
\hline & Value & df & Asymptotic significance (bilateral) \\
\hline Chi-square of Pearson & $14,981^{\mathrm{a}}$ & 9 &, 091 \\
Reasonableness & 14,968 & 9 &, 092 \\
Linear association by linear & 3,143 & 1 &, 076 \\
N of valid cases & 394 & & \\
\hline
\end{tabular}

a. 5 cells $(31.3 \%)$ have expected a count of less than 5 . The expected minimum count is, 39 . 
In Table 3, we are presented with a chi-square value and an asymptotic significance, greater than 0.05, by which we can say that we accept the null hypothesis and, consequently, we affirm that the variables are not dependent on each other.

Table 4. Symmetric measurements

\begin{tabular}{|c|c|c|c|}
\hline & & Value & Approximate significance \\
\hline Nominal by Nominal & Contingency coefficient & ,191 & ,091 \\
\hline \multicolumn{2}{|c|}{$\mathrm{N}$ of valid cases } & 394 & \\
\hline
\end{tabular}

In Table 4 we can see that, as in the case of the chi-square, that the contingency coefficient is not enough to accept the alternative hypothesis, since we see that it reaches a low value (0.191), although with a degree of significance. 091 that does not allow to fully accept the null hypothesis of nondependence between the variables.

However, according to the attached illustration 2, we can clearly see the predominance, of the positive affects over the negative ones, in the interval of 10 to 11 years, superior to other intervals, predominance that turns out to be quite superior to the one that results in the others age ranges.

Moreover, in this Illustration, as in number 3, the results cannot be interpreted in the same way as in the crossed tables, since the number of subjects for each age interval is variable.

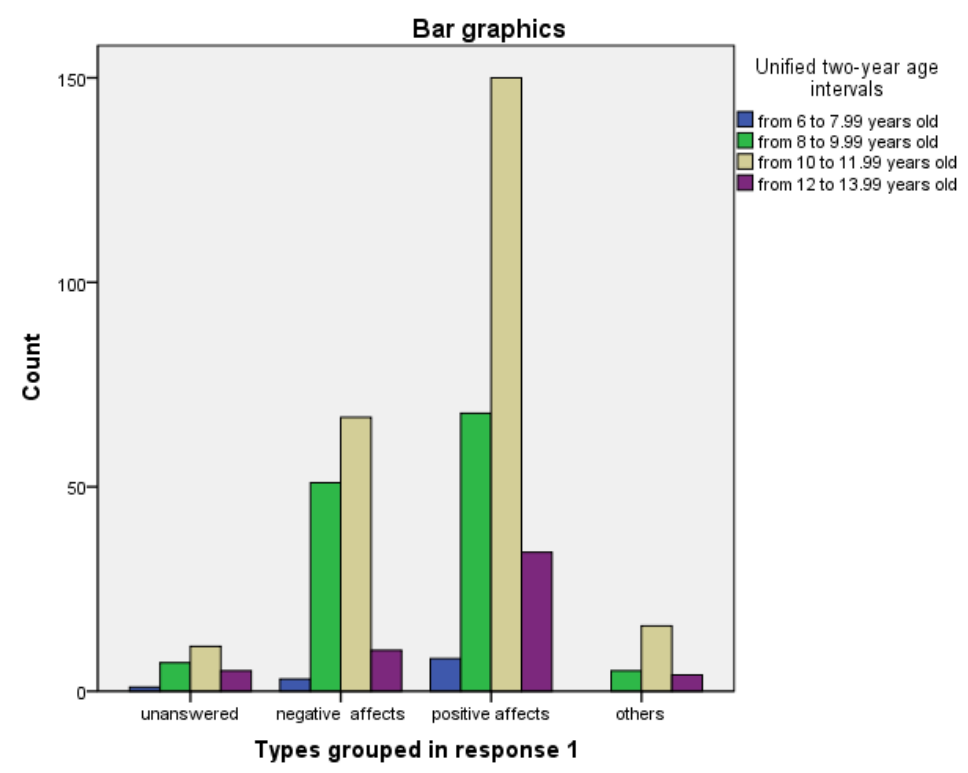

Figura 2. Types grouped in response 1

\subsubsection{Overall results, in grouped types}

As a complement to this data, we also took into account all the answers given in the T.D.E. for each boy or girl. This gives us a clear predominance of the "negative" affects over the positive ones, which contrasts with the results obtained with the first response given. We are inclined to interpret this situation considering that culture tends to give more importance to "negative" affects ${ }^{7}$, while in the first response the predominantly optimistic mood of young people and children is expressed. All this is shown below in Table 5 .

Table 5. Number of responses by types of affectiona

\footnotetext{
${ }^{7}$ However, this predominance could have a biological basis: "On the contrary, there are fewer neurons that respond to images capable of inducing pleasant emotions, and they do so without the brake and march pattern that corresponds to neurons adjusted to unpleasant sensations." (Damasio, 2014: 75).
} 


\begin{tabular}{cccccc}
\hline Number of answers & Totals & "negative" affects & "positive" affects & "valid" & "no valid" \\
\hline & 4806 & 2352 & 1503 & 3855 & 951 \\
\hline
\end{tabular}

If we complement these results with those of Table 6, which appears below, we can first observe the high percentage of "invalid" answers, of almost 20\%, which seems to indicate that there is a significant percentage of doubt about what they are affected or emotions and what are not. Second, the predominance of almost $2 / 3$ of the "negative" affects over the "positive ones". And thirdly, the indicative figure of the repertoire of affections that each child knows, although this figure will acquire greater significance when compared with what we obtained with the students of Secondary School, which is higher (Tables 11 and 12).

Table 6. Percentages of response types in Primary

\begin{tabular}{l|c}
\hline percentage of "valid" answers & $80,2122 \%$ \\
\hline percentage of "invalid" answers & $19,7878 \%$ \\
\hline percentage of "negative" affects & $61,0117 \%$ \\
\hline percentage of "positive" affects & $38,9883 \%$ \\
\hline number of responses per student & 10,7277 \\
\hline
\end{tabular}

\subsection{Results in Secondary}

A similar result, but not the same, we find Secondary students. In this case the sample is somewhat higher, although the main age interval is narrower, so the sample has more weight. Of the total sample (471) there are hardly any missing values, because almost all the subjects put their date of birth (see Table 7).

Table 7. Case processing summary

\begin{tabular}{l|c|c|c|c|c|c}
\hline & \multicolumn{3}{|c}{ Cases } & \multicolumn{2}{c}{ Total } \\
\cline { 2 - 7 } & \multicolumn{2}{|c|}{ Valid } & \multicolumn{2}{c|}{ Lost } & \multicolumn{2}{c}{} \\
\cline { 2 - 7 } & $\mathrm{N}$ & Percentage & $\mathrm{N}$ & Percentage & $\mathrm{N}$ & Percentage \\
\hline Grouped response types * Age intervals every 2 years & 470 & $99,6 \%$ & 2 & $0,4 \%$ & 472 & $100,0 \%$ \\
\hline
\end{tabular}

In the following table (Table 8) is where we find the most significant data, reflecting in them, again, a period of "crisis" that goes from 12 years until the age of 16, where the "negative" affects predominate over the "positives"; but with an especially intense alteration between 14 years and 14 and 6 months (Morgado, 2013).

Table 8. Cross-tabulated response types grouped * Age intervals every 2 year

\begin{tabular}{|c|c|c|c|c|c|c|c|c|c|}
\hline & & & \multicolumn{6}{|c|}{ Age intervals every 2 year } & \multirow[b]{2}{*}{ Total } \\
\hline & & & $\begin{array}{c}\text { No } \\
\text { data }\end{array}$ & $\begin{array}{c}\text { From } 10 \\
\text { to } 11.99 \\
\text { years }\end{array}$ & $\begin{array}{c}\text { From } 12 \\
\text { to } 13,99 \\
\text { years }\end{array}$ & $\begin{array}{c}\text { From } 14 \\
\text { to } 15,99 \\
\text { years }\end{array}$ & $\begin{array}{c}\text { From } 16 \\
\text { to } 17,99 \\
\text { years }\end{array}$ & $\begin{array}{c}\text { From } 18 \\
\text { to } 19,99 \\
\text { years }\end{array}$ & \\
\hline \multirow{8}{*}{$\begin{array}{l}\text { Response } \\
\text { types } \\
\text { grouped }\end{array}$} & \multirow{2}{*}{ Unanswered } & Count & 5 & 0 & 6 & 5 & 5 & 0 & 21 \\
\hline & & Expected count &, 2 & ,3 & 8,5 & 8,3 & 3,4 &, 3 & 21,0 \\
\hline & \multirow{2}{*}{$\begin{array}{c}\text { "Negative" } \\
\text { affects }\end{array}$} & Count & 0 & 2 & 67 & 68 & 15 & 4 & 156 \\
\hline & & Expected count & 1,7 & 2,0 & 63,1 & 61,7 & 25,2 & 2,3 & 156,0 \\
\hline & \multirow{2}{*}{$\begin{array}{c}\text { "Positive" } \\
\text { affects }\end{array}$} & Count & 0 & 4 & 111 & 107 & 54 & 1 & 277 \\
\hline & & Expected count & 2,9 & 3,5 & 112,0 & 109,6 & 44,8 & 4,1 & 277,0 \\
\hline & \multirow{2}{*}{ Others } & Count & 0 & 0 & 6 & 6 & 2 & 2 & 16 \\
\hline & & Expected count &, 2 &, 2 & 6,5 & 6,3 & 2,6 &, 2 & 16,0 \\
\hline
\end{tabular}




\begin{tabular}{cl|c|c|c|c|c|c|c}
\hline \multirow{2}{*}{ Total } & Count & 5 & 6 & 190 & 186 & 76 & 7 & 470 \\
& Expected count & 5,0 & 6,0 & 190,0 & 186,0 & 76,0 & 7,0 & 470,0 \\
\hline
\end{tabular}

However, in this case, there is a dependency between types of affects and age intervals, and the validity of these data is corroborated by the values of chi-square and the contingency coefficient, as shown in the following tables.

Table 9. Chi-square tests

\begin{tabular}{cccc}
\hline & Value & df & Asymptotic significance (bilateral) \\
\hline Chi-square of Pearson & $134,334^{\mathrm{a}}$ & 15 &, 000 \\
Reasonableness & 52,878 & 15 &, 000 \\
Linear association by linear & 7,306 & 1 &, 007 \\
N of valid cases & 470 & & \\
\hline
\end{tabular}

a. 14 cells $(581.3 \%)$ have expected a count of less than 5 . The expected minimum count is.17.

Therefore, according to this asymptotic significance, less than 0.05 , we can say that we reject the null hypothesis and, consequently, we affirm that the variables are dependent on each other.

Table 10. Symmetric measurements

\begin{tabular}{|c|c|c|c|}
\hline & & Value & Approximate significance \\
\hline Nominal by Nominal & Contingency coefficient & ,471 & 000 \\
\hline \multicolumn{2}{|c|}{$\mathrm{N}$ of valid cases } & 470 & \\
\hline
\end{tabular}

If we analyze the previous coefficient of contingency, we see that it reaches a mean value (0.471), with a degree of significance.000 that allows us to reject also the null hypothesis.

On the other hand, Figure 3 complements the statistical data with the observation that positive affects are higher in these age ranges, especially after 16 years.

However, when the overall results were taken into account, the predominant affects were negative, both in children and adolescents. As we see below in Tables 11 and 12; having in this case the "positive" affects more weight than with the Primary students. As we said before, the graphs (illustrations 2 and 3) offer somewhat different results to the crossed tables, since the number of subjects by age ranges is different from one to another.

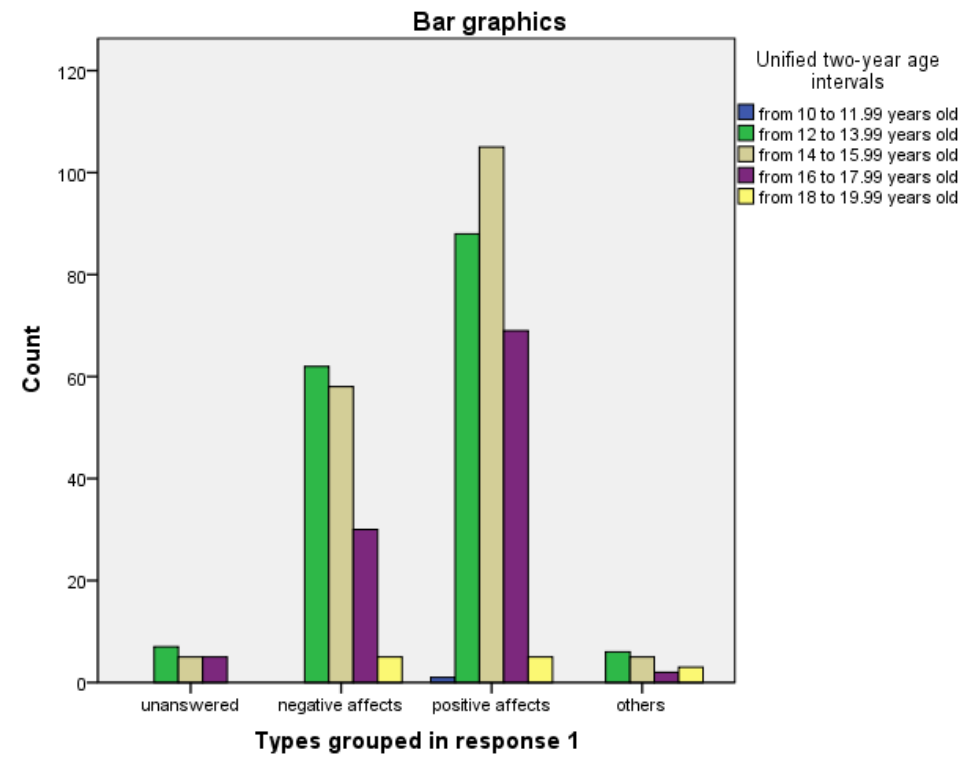


Figure 3. Types grouped in rersponse 1. Secundary

Table 11. Number of answers in Secundary

\begin{tabular}{cccccc}
\hline Number of answers & Totals & "negative" affects & "positive" affects & "valid" & "no valid" \\
\hline & 7490 & 3885 & 2427 & 6312 & 1178 \\
\hline
\end{tabular}

Table 12. Oercentage of responses in Secundary

\begin{tabular}{l|l}
\hline percentage of "valid" answers & $84,4189 \%$ \\
\hline percentage of "invalid" answers & $15,7550 \%$ \\
\hline percentage of "negative" affects & $51,9593 \%$ \\
\hline percentage of "positive" affects & $32,4595 \%$ \\
\hline number of responses per student & 15,841101 \\
\hline
\end{tabular}

\section{Conclusions}

From all the above and from the results obtained, we have revealed the existence of periods in which, in children and adolescents, the negative affects predominate over positive ones. These periods we suspect could correspond to stages of disequilibrium, psychological imbalance and, consequently, a reduction in resilience. The observation of the existence of these periods would prevent us from drawing a complete parallelism between cognitive development (defined from Piaget in a progressive and more linear way, although with moments of brake and acceleration interspersed) and affective, as it could have been our intention or of others like Guin-Decarie, or Piaget himself (Morgado, 1986). In this way, there are clear differences between one development and another, a detail that warns us about the possibly inadequate parallelism between cognitive development and affective development, in addition to pointing out some inadequacy of the term emotional intelligence, to which usually we relate to this one.

In addition, when the overall results were taken into account, a pre-domino of the negative affects was obtained. This factor we suspect may be cultural and not endogenous; that is, it may be because society in general favors more the development of negatives and is not due to a "natural" genetic-evolutionary development; but, possibly, it is because the constrictive character of the culture (as a carrier of norms and regulations) makes it pay more attention to the negative than to the positive affects ones, or at least makes them stand out more about the positive

On the other hand, we can associate periods of imbalance in affective development with moments of lower resilience, during which the person self-perceives himself as more vulnerable and reacts to that perception with fear, anger, insecurity... All of which will also allow us to put in question a concept of resilience that understands this as a permanent state in which we have sufficient capacity to react to adversity $^{8}$, or disability in those other people considered less fortunate or less healthy mentally. Instead, we will opt for a concept of resilience in which the person presents in each person more or less profound oscillations, not necessarily in a certain direction, according to the precepts of a unilinear evolutionism. However, we can consider, unless evidence to the contrary, that in each person there are more or less marked tendencies to have periods of variable duration of a high or low resilience, without having to resort to clinical models or psychopathic-logical. We would then speak of oscillations within "normality".

We could also say that, in "failed" moments, in which crises have not led to the resolution of conflicts, a repetition of those crises may be needed, "to try again"; although in this work, due to its design, we have not found empirical evidence of this. But, again, this idea invites us not to alarm too loudly when these crises are repeated, and leads us to consider these situations, within the normality of affective development processes. If not to question the very principle of normality, both the statistic and the conceptual, true origin of the first.

In future research, it will surely be useful to compare the results obtained in the ones presented here with those obtained with the personality adjustment tests, such as the S.D.Q. (Strengths and Difficulties

\footnotetext{
${ }^{8}$ Rutter (2010) states that resilience is "the phenomenon by which individuals achieve relatively good results despite being exposed to adverse experiences". In Cabanyes Truffino (2010: 146).
} 
Questionnaire, in Ortuño Sierra, 2014), or any other Allow Evaluate both emotional adjustment and resilience.

In education, it will surely be useful to know the implications of some of the relationships between affectivity, ethics, adjustment and resilience, which we have seen here. Especially to be able to carry out the generalized emotional education of today, not in a stereotyped way, based on a repertoire of activities that someone has given good results somewhere in the world, but in a way adjusted to a good knowledge of the evolution of the human affectivity. And other aspects related to personality.

\section{References}

1. E. Becoña (2006). Resiliencia: definición, características y utilidad del concepto. Revista de Psicopatología y Psicología Clínica Vol. 11, № 3, pp. 125-146,2006.

2. Y. Benito (Coord.) (1992, 2a edición): Desarrollo y educación de los niños superdotados. Salamanca, Amarú Ediciones.

3. J. Cabanyes Truffino (2010). Resiliencia: una aproximación al concepto. Revista de Psiquiatría y Salud Mental (Barcelona) 2010; 3(4): 145-151.

4. K. Dabrowski \& M. M. Piechowski (1977). Theory of levels of emotional development. Vols I y II. Oceanside, NY: Dabor Science Publications. En Pardo de Santayana (2004).

5. A. Damasio $(2014$ (2003)). En busca de Spinoza. Neurobiología de la emoción y los sentimientos. Barcelona: Destino, Planeta. Colecc. Booket. (1ª edición de 2003).

6. Damasio (2016 (1995)). El error de Descartes. Las emociones, la razón y el cerebro humano. Barcelona: Booket. Destino, Planeta. Colecc. Booket. (1 $1^{\mathrm{a}}$ edición de 1995).

7. R. Descartes (1995 (1649). Tratado de las pasiones del alma. Barcelona: Planeta DeAgostini, Obras maestras del Milenio.

8. Espinoza (1980 (1675)). Ética demostrada según el orden geométrico. Trad. De Vidal Peña. Madrid: Ediciones Orbis, S. A. Hyspamérica.

9. L. Fernández-Ríos and M. Vilariño (2016). Mitos de la psicología positiva: maniobras engañosas y pseudociencia. Papeles del psicólogo, vol. 37, 2016, pp. 134-142. Madrid: Consejo General de la Psicología de España.

10. S. C. Fulquez Castro (2010). La inteligencia emocional y el ajuste psicológico: un estudio transcultural. Tesis doctoral, leída en la Universidad Ramón Llull de Barcelona.

11. Galati and B. Sini (2000). Las estructuras semánticas del léxico francés de las emociones. En Plantin, Christian; Doury, Marianne y Traverso, Véronique Les emotions dans les interactions, pp. 75-87. Lyon: Presses universitaires de Lyon. Collection Ethologie et Psychologie des Communications.

12. P. Gallardo Vázquez (2007). El desarrollo emocional en la Educación Primaria (6-12 años). Cuestiones Pedagógicas, 18, 2006/2007, pp. 143-159. Sevilla: Secretariado de Publicaciones Universidad de Sevilla.

13. M. C. García-Vesga \& E. Domínguez-de la Ossa (2013). Desarrollo teórico de la Resiliencia y su aplicación en situaciones adversas: Una revisión analítica. Revista Latinoamericana de Ciencias Sociales, Niñez y Juventud, 11 (1), pp. 63-77.

14. J. M. George (2000). Emotions and leadership: The role of emotional intelligence. Human Relations. [00187267(200008)53:8]. Volume 53(8): 1027-1055: 013316. The Tavistock Institute ®. SAGE Publications. London, Thousand Oaks CA, New Delhi.

15. H. Grotberg (2003). Nuevas tendencias en resiliencia, in Melillo, Aldo y Suárez Ojeda, Elbio Néstor (eds.). Resiliencia, descubriendo las propias fortalezas. Buenos Aires: Paidós.

16. Grotberg, Edith Henderson (2006). La resiliencia en el mundo de hoy: cómo superar las adversidades. Barcelona: Gedisa.

17. J. A. Marina Torres (2011). Pequeño tratado de los grandes vicios. Barcelona: Editorial Anagrama. Colección Argumentos.

18. R. Morgado Giraldo (1986). Estudio general de la afectividad y de las variables que influyen en su desarrollo. Bachelor thesis (unpublished). Sevilla, enero de 1986.

19. R. Morgado Giraldo (2008). Desarrollo emocional y rendimiento académico, en las I Jornadas Andaluzas de Innovación e Investigación Educativa. Organizadas por la Dirección general de Innovación educativa de la Consejería de Educación de la Junta de Andalucía; celebradas en Granada (Palacio de Congresos) del 29 al 30 de octubre de 2008. 
20. R. Morgado Giraldo (coordinador) and G. Granadilla; M. Coronilla; M. I. Perea; A. Martínez and F. J. Lozano (2013). El vocabulario emocional como punto de partida para la educación emocional. En el XVI Congreso Nacional y II Internacional AIDIPE, bajo el lema "Investigación e Innovación Educativa al Servicio de Instituciones y Comunidades Globales, Plurales y Diversas", celebrado en Alicante los días 4, 5 y 6 de septiembre de 2013.

21. R. Morgado Giraldo (2015a). La medición del desarrollo emocional. XVII Congreso Internacional de Investigación Educativa, con el lema "Investigar con y para la sociedad". Organiza AIDIPE, del 24 al 26 de junio en Cádiz.

22. R. Morgado Giraldo (2015b). El desarrollo emocional en Primaria. I Congreso Internacional de Expresión y Comunicación Emocional. Organiza AIECE en Sevilla, 2, 3 y 4 de septiembre de 2015.

23. R. Morgado Giraldo (2015c). Distintos procedimientos para establecer el número de afectos. I Congreso Internacional de Expresión y Comunicación Emocional. Organiza AIECE en Sevilla, 2, 3 y 4 de septiembre de 2015.

24. R. Morgado Giraldo (2017). Desarrollo moral y afectivo. Interdependencia entre ambos. Actas II Congreso Internacional de Expresión y Comunicación Emocional. Sevilla.

25. J. Ortuño Sierra (2014). Adolescencia. Evaluación del ajuste emocional y comportamental en el contexto escolar. Universidad de La Rioja. Departamento de Ciencias de la Educación.

26. R. Pardo de Santayana Sanz (2004). La teoría de la desintegración positiva de Dabrowski. Revista Complutense de Educación. Vol. 15 Núm. 2 431-450. Universidad de Cantabria.

27. R. Plutchik (1983a). A General Psychoevolutionary Theory of Emotion. En Plutchik, Robert y Kellerman, Henry. Emotion. Theory, Research, and Experience, Volume 1. Theories of Emotion. Chapter 1. New York-London: Academic Press.

28. R. Plutchik (1983b). Emotions in Early Development: A Psychoevolutionary Approach. In Plutchik, Robert and Kellerman, Henry. Emotion. Theory, Research, and Experience, Volume 2, Emotions in Early Development, Chapter 8. New York-London: Academic Press.

29. M. Rutter (2006). Implications of resilience concepts for scientific understanding. Ann N Y Acad Sci. 2006; 1094:1-12.

30. M. E. Seligman (2006 (2002)). La auténtica felicidad. Barcelona: Ediciones B.

31. V. Serrano (2011). La herida de Spinoza. Felicidad y política en la vida posmoderna. Barcelona: Editorial Anagrama. Colección Argumentos.

32. L. K. Silverman (1992). How parents can support gifted children. (ERIC Document Reproduction Service № ed. $352766)$.

33. L. K. Silverman \& K. Kearney (1992). The case for the Stanford-Binet L-M as a supplemental test. Roeper Review, 15 (1), 34-37.

34. S. Vinaccia, J. M. Quiceno and E. Moreno San Pedro (2007). Resiliencia en adolescentes. Revista Colombiana de Psicología, no. 16, 2007. Bogotá Colombia, pp. 139 -146. 